\title{
Evaluate the Factors Related to the Level of Community Satisfaction on Community Empowerment Activities
}

\author{
Aris Slamet Widodo ${ }^{1, *}$ \\ ${ }^{1}$ Agribusiness, Universitas Muhammadiyah Yogyakarta
}

\begin{abstract}
This research aims to analyze the empowerment programs, activities and evaluate the factors related to the level of community satisfaction towards empowerment program. Location of the study was determined by purposive method in the Karangsari Village, Sapuran District, Wonosobo Regency. Respondents in this study were 26 people who were taken by purposive which is the community that received the empowerment program. The correlation analysis (rank spearman) is used to determine the relation between factors with the level of community satisfaction. The results of the analysis showed that most of the programs implemented were about waste management, where the empowerment activities carried out were mostly socialization, and the beneficiary community in the empowerment program were the general public. Factors related to satisfaction level such as accuracy of innovation, problem solving assistance, community confidence in the success of the program and community perception that empowerment gives positive values in the form of new knowledge, changes in behavior and attitudes, and can improve the economy The accuracy of the innovation, the mentoring process, the belief in the success of the program and the added value has a correlation with the level of community satisfaction with the $99 \%$ confidence level.
\end{abstract}

\section{Introduction}

Community development is a social phenomenon which is a process of changing living conditions to become more prosperous and has been going on since humans have lived in societies. This is because the community is constantly in the process of changing conditions for the better [1]. Governments with their resources and inherent authority often experience obstacles in the development process, such as the still centralized development pattern [2]. Another obstacle is the low level of community income and the lack of initiative from village officials in exploiting potential [3].

Sustainable community development can be done through empowerment [4]. The indicator is the increase of independence, community empowerment, and economic income generation [5]. According to [5,6] community-local government participatory development

\footnotetext{
* Corresponding author: armando1215sw@gmail.com
} 
strategies can attain strong local ownership and empowerment among rural communities. Institutional is necessary to apply the concept of empowerment, and social transformation will take place mainly through education, mentoring and evaluation [8].

Empowerment means making something empowered or having power or having strength $[9,10]$. The meaning of empowerment according to the government is an effort to encourage people to live independently, to increase physical and non-physical measurements in people's lives. Empowering the community is an effort to increase the dignity and dignity of people who have not been able to escape the traps of poverty, ignorance, and backwardness, so that community empowerment is not only strengthening individuals but also existing social institutions [11].

According to [12] and [13] in [14] state that empowerment is essentially enabling a person to be more advanced and independent as well as efforts to generate resources, which means making someone prosperous. Prosperous get the opportunity and ability to obtain basic rights as a human being. Community empowerment is significantly related to the sense of community and strong collaboration among local communities $[15,16]$. To further sharpen the achievement of empowerment programs, the support of knowledge about local socio-cultural strengths is very important [17].

One of the institutions that play a role in the empowerment program is LP3M (Board of Research, Publication, and Community Service) [18]. The purpose of empowerment is to empower individuals and groups through capacity building (including consciousness, knowledge, and skill) that required to change the quality of life of the society [13] in [14]. Universitas Muhammadiyah Yogyakarta through LP3M has conducted several empowerment programs and one of them is located in Karangsari, Wonosobo.

Karangsari village which is located in the sub-district of Sapuran, Wonosobo is an area with potential in coffee plantations and currently has a village-based tourism development program. Community empowerment in Karangsari in 2019 was focused on self-sufficient waste management, assistance for river tubing tourism managers, and village government website management. The success of self-sufficient waste management by the community is expected to be the main door towards a village-based tourism development program. Tourism development has provided several positive impacts, and that local community members encountered many benefits that ventured beyond economic factors [19]. An integrative perspective is necessary to fully understand how to empower neighborhoods, particularly in the face of structural challenges [20,21].

The level of satisfaction on the community can be measured from the success of planning, implementation, and the result of the empowerment program that has been executed. Data retrieval in the research of satisfaction can be done with the observation, documentation, and questionnaire [22]. According to [23], satisfaction is the level of someone's feeling after comparing a performance or result that is perceived with his expectation. In line with [23], [24] explained that the defining factor of satisfaction on the community can be seen from the perception of service quality obtained.

The perception is the core of communication, while interpretation is the core of perception [25]. The Interpretation itself is identic with decoding inside a communication process. This idea strengthens the definition of [26] that perception can be defined as a way of an organization to give meaning." Perception is called the core of communication because if the perception is not accurate, the communication can be effective [27].

The presence of empowerment activity in LP3M UMY, certainly the perception of satisfaction on the community towards the program of community service will be different. Thus it is necessary to know that the level of satisfaction of community towards community service program that has been implemented and what factors influence the level of satisfaction on community towards the community service program in Karangsari.

The purpose of this research is (1) to know the perception of the level of satisfaction on 
the community towards a community service program, and (2) evaluate the factors related to the level of community satisfaction towards empowerment program.

\section{Research Method}

The basic method used in this research is to use the descriptive analysis method, namely a study that focuses on solving problems that exist in the present, data is collected, compiled, explained then analyzed. The descriptive analysis method provides an overview of phenomena, and also explains relationships, tests hypotheses, makes predictions, and gets the meaning and implications of the problem to be solved [28].

The determination of the location was carried out using the purposive method, namely in Karangsari Village, Sapuran District, Wonosobo Regency, which has collaborated and received the LP3M empowerment program at Universitas Muhammadiyah Yogyakarta for the odd period of 2019/2020. The determination of respondents in this study using the purposive method (deliberately), namely by taking community respondents who are actively involved in empowerment activities. In 1 village there are 5 hamlets and 5 respondents in each hamlet. Respondents in each hamlet consisted of 1 hamlet head, 2 independent waste cadres/managers, and 2 community members. Researchers also made Karangsari Village Apparatus as respondents.

The scope of empowerment that is carried out is the sadaqah trash program, assistance for river tubing managers, and optimization of village websites. The type of data used is primary data and data collection techniques with observation and interview techniques. The analysis used is descriptive analysis and scoring analysis followed by Rank Spearman's analysis.

\section{Result and Discussion}

\subsection{Perception of The Level of Satisfaction on Community}

The perception of the level of community satisfaction is a direct response (acceptance) of something that is received. Perception is a process that involves the entry of messages or information in the human brain continuously making contact with their environment. In this study, perceptions of the level of community satisfaction seen from the factors related to the level of community satisfaction consist of indicators of innovation accuracy, mentoring process, belief in success, and added value.

Table 1. Indicator of Perception of Community Satisfaction Level

\begin{tabular}{|l|c|c|c|c|c|c|c|c|}
\hline \multirow{2}{*}{ Indicator } & \multicolumn{5}{|c|}{$\begin{array}{c}\text { Respondent Score } \\
\text { Distribution }\end{array}$} & $\begin{array}{c}\text { Score } \\
\text { Range }\end{array}$ & $\begin{array}{c}\text { Score } \\
\text { Average }\end{array}$ & Category \\
\cline { 2 - 7 } & $\mathbf{1}$ & $\mathbf{2}$ & $\mathbf{3}$ & $\mathbf{4}$ & $\mathbf{5}$ & & & \\
\hline Accuracy of Innovation & 0 & 0 & 1 & 20 & 5 & $1-5$ & 4.15 & Good \\
\hline Assistance Process & 0 & 0 & 2 & 14 & 10 & $1-5$ & 4.31 & Very Good \\
\hline Belief of Program Success & 0 & 0 & 0 & 15 & 11 & $1-5$ & 4.42 & Convinced \\
\hline Value-added & 0 & 0 & 0 & 14 & 12 & $1-5$ & 4.46 & Very High \\
\hline
\end{tabular}

Source: Main Data

Information:

Very Incorrect/Good/Sure/High $\quad: 1.00-1.80$

Incorrect/Good/Sure/High $\quad: 1.81-2.60$

Less Correct/Good/Sure/High $\quad: 2.61-3.40$

Correct/Good/Sure/High $\quad: 3.41-4.20$

Very Correct/Good/Sure/High $\quad: 4.21-5.00$ 
In table 1 , the indicator of the accuracy of innovation has an average score of 4.15 and is in the right category. The results of community perceptions are influenced by the existence of an innovation program that is understood by the community, namely the waste sorting program, sadaqah waste, SOPs for organizing tubing tours, and using the website for promotion. The community feels that this innovation can bring good change and is suitable for the problems currently being faced. The selection of innovations was also produced from the FGD (focus group discussion) process between the facilitator and community representatives. The use of an innovation is one of the keys to successful community empowerment [29].

The indicator for the process of programming assistance to problem-solving has an average score of 4.31 which means that the indicator is in a very good category. The community gives the perception that the facilitator can assist every problem-solving in the hamlet. The facilitator is truly attached to and processes with the community at each stage of empowerment. The meeting stages in outreach, training, and home assistance activities at the sadaqah waste movement stage are truly felt by the community.

Indicators of the assurance in the program's success, the whole community gave a very strong perception of its success with an average score of 4.42 . Public assurance is possible to be supported by the planning made jointly between the facilitator and the community to the determination of the implementation time as well as the public interest in participating in the various programs implemented. This condition is in line with the opinion of [30] that community facilitators must encourage people to bravely participating in expressing opinions, ideas, and thoughts in the decision-making process by taking into account and considering cultural characteristics, social values, and regulations in society.

The indicator of added value in the empowerment process has an average score of 4.46 which means it is in the very high category. The public perception that there is added value seen from the perspective of community empowerment provides new knowledge and brings change for the better. The added value of changes in the waste management program includes disposing of garbage in its place, sorting waste, and a healthier environment. While the website management program is the community's concern for the condition of the village, especially the social aspect, and all programs are expected to be able to improve the economy.

The high perception of the level of community satisfaction does not mean that there are no obstacles in the process of implementing empowerment. Village governments often face the constraint of the limited number of cadres. [31] also informed the obstacles that are often faced in empowerment, namely a limited understanding of the community and limited operational personnel.

\subsection{Factors Related to the Level of Community Satisfaction}

Factors related to the level of community satisfaction with the village community empowerment program consist of indicators including the accuracy of innovation, the mentoring process, assurance in the success of the program, and added value. These factors will later affect the level of satisfaction felt by the community in the empowerment program that has been implemented. The following is the data regarding the level of correlation of factors related to the level of satisfaction in tabulated form.

Based on the data regarding the correlation level of factors related to the level of community satisfaction with the village community empowerment program in table 2 above, it can be seen that: 
Table 2. Factors Related to Community Satisfaction Level

\begin{tabular}{|c|l|c|l|}
\hline No & Factors & Rs Grade & Significance \\
\hline 1 & Innovation Accuracy & 0.598 & $* * 0.001$ \\
\hline 2 & Process of Assistance & 0.685 & $* * 0.000$ \\
\hline 3 & Belief of Success & 0.608 & $* * 0.001$ \\
\hline 4 & Value-added & 0.518 & $* * 0.007$ \\
\hline
\end{tabular}

Source: Main Data.

Information:

**) Significance of Correlation on $\alpha 1 \%$.

*) Significance of Correlation on $\alpha 5 \%$.

\subsubsection{The relationship between the accuracy of innovation and the level of satisfaction}

The indicator of the accuracy of innovation is positive with a significant level of satisfaction of 0.001 so it has a value of $<0.01$ or significant at the $99 \%$ level of trust. This means that $\mathrm{Ho}$ is rejected and $\mathrm{Ha}$ is accepted, then the conclusion is that there is a relationship between the accuracy of innovation and appropriate technology with the level of community satisfaction with a positive correlation value meaning that the relationship between these indicators is unidirectional. It can be explained that the accuracy of innovation in the form of precise use of appropriate technology such as sorting waste and sadaqah waste, techniques for using tubing equipment, and utilizing websites that are used are correct so that the community provides a satisfying assessment of the program being implemented. The accuracy of innovation, including technology, can be seen from changes in a positive direction such as the community is easier in managing waste, the community is safer when accompanying tubing tourists in the river and the community is easier in managing websites.

\subsubsection{The Relationship between Mentoring Process and Satisfaction Level}

The relationship between the mentoring process indicator and the level of satisfaction is positive with a significant level of satisfaction of 0.000 , so it has a value of $<0.01$ or at the $99 \%$ confidence level. This means that Ho is rejected and $\mathrm{Ha}$ is accepted, it can be concluded that there is a relationship between the mentoring process and the level of community satisfaction. This can be explained that the assessment of the level of community satisfaction with satisfaction in the mentoring process has a positive correlation meaning that the relationship between these indicators is unidirectional. The mentoring process carried out by the facilitator has a positive impact on the community such as the community is easier to apply the concept of sadaqah waste, easier to use tubing equipment, and easier to manage website content. This mentoring process is said to be very important because the program is said to be successful if the mentoring process runs well from the start of program planning, program implementation until finally there is a change in community behavior and later the community can be independent.

\subsubsection{The relationship between program success beliefs and satisfaction levels}

The Program Success Confidence Indicator is an assessment of the level of community satisfaction related to the confidence of the community who will receive the empowerment program. From the beginning of the planned program, the community must be sure that the program will be successful, the community will receive positive feedback as well as believe that there will be a change in attitudes in the community for the better, making the 
community more aware of the importance of living in groups. The relationship between the indicators of success confidence and the level of satisfaction is positive with a significance level of satisfaction of 0.001 so it has a value of $<0.01$ or at the $99 \%$ confidence level. This means that Ho is rejected and $\mathrm{Ha}$ is accepted, it can be concluded that there is a relationship between the belief in program success and the level of community satisfaction with a positive correlation value so that the relationship between these indicators is unidirectional. The community will judge they are satisfied if the community is sure of the success of the program to be implemented. The belief in success is formed because the community is well facilitated from the process of program preparation, determining the implementation time, and carrying out FGD (focus group discussions) in solving existing problems.

\subsubsection{The relationship between value-added indicators and the level of satisfaction}

The relationship between value-added indicators and the level of satisfaction is positive with a significance level of satisfaction of 0.007 , so it has a value of $<0.01$ or at the $99 \%$ confidence level. This means that Ho is rejected and Ha is accepted, it is the same as the other three indicators that this indicator has a relationship between the value-added indicator and the level of community satisfaction. It is explained that the assessment of the level of community satisfaction with the value-added indicator, the correlation is positive, meaning that the indicator relationship is unidirectional. The empowerment program provides added value in the form of broad insight into the community, knowledge about the potential of natural resources that can be developed through training to provide increased economic income for the community and their hamlet. The program ultimately increased community satisfaction.

\section{Conclusion}

1. The community has the right perception of using innovation, is very good in the mentoring process, is very confident in the success of the empowerment program, and has a perception of providing very high added value.

2. Indicators of the accuracy of innovation, mentoring process, belief in the success of the program, and added value have a positive or unidirectional relationship with the level of community satisfaction with a trust level of $99 \%$.

\section{References}

1. Soetomo, Keswadayaan Masyarakat: Manifestasi Kapasitas Masyarakat untuk Berkembang secara Mandiri (Pustaka Pelajar, Yogyakarta, 2012).

2. A. Luthfia, Rizka, J. Rural Dev. IV, 135 (2013).

3. S. Koeswantono W, Sarwahita 11, 82 (2017).

4. J. N. Kimengsi és S. A. Gwan, Int. J. Emerg. Trends Soc. Sci. 1, 53 (2017).

5. D. Hidayat és A. Syahid, J. Nonform. Educ. 5, 1 (2019).

6. M. S. Ahmad és N. B. Abu Talib, Qual. Quant. 49, 827 (2015).

7. S. Rolfe, Local Gov. Stud. 42, 97 (2016).

8. M. I. Mufti, I. Kurnia, I. Karim, és M. A. Samad, Int. J. Multicult. Multireligious Underst. 7, 16 (2020).

9. S. L. Sa'adah, J. Kaji. Ekon. Dan Bisnis Islam 1, 93 (2014). 
10. T. Winarni, Memahami Pemberdyaan Masyarakat Desa Partisipatif dalam Orientasi Pembangunan Masyarakat Desa menyongsong abad 21: menuju Pemberdayaan Pelayanan Masyarakat (Aditya Media, Yogyakarta, 1998).

11. M. Noor, J. Ilm. Civ. 1, (2011).

12. Suprajan és Hempri Suyatno, Pengembangan Masyarakat dari pembangunan Sampai Pemberdayaan (Aditya Media, Yogyakarta, 2003).

13. S. Edi, membangun masyarakat memberdayakan rakyat, bandung:Refika Aditama (Refika Aditama, Bandung, 2010).

14. S. K. Widiastuti és dkk, Pemberdayaan Masyarakat Marginal (Pustaka Pelajar, Yogyakarta, 2015).

15. M. S. Ahmad és N. B. Abu Talib, Soc. Indic. Res. 129, 1039 (2016).

16. E. Park és S. Kim, Tour. Plan. Dev. 13, 351 (2016).

17. T. Pranadji és E. L. Hastuti, J. Anal. Kebijak. Pertan. 2, 77 (2004).

18. A. S. Widodo, Teknik Fasilitasi Pemberdayaan Masyarakat (UMY Press, Yogyakarta, 2019).

19. G. Butler, J. Tour. Cult. Chang. 15, 199 (2017).

20. S. M. Aiyer, M. A. Zimmerman, S. Morrel-Samuels, és T. M. Reischl, Heal. Educ. Behav. 42, 137 (2015).

21. Z. Chen, L. Li, és T. Li, Tour. Manag. 58, 276 (2017).

22. S. Suandi, J. Ilmu Adm. dan Stud. 1, 13 (2019).

23. Supranto, Pengukuran Tingkat kepuasan Pelanggan (Rineka Cipta, Jakarta, 1997).

24. R. Lupiyoadi, Manajemen Pemasaran Jasa (Salmba Empat, 2006).

25. S. Susanto és M. Iqbal, CARADDE J. Pengabdi. Kpd. Masy. 2, (2019).

26. J. R. and W. W. W. Harvey London, Wenburg, Public Opin. Q. 38, 154 (1974).

27. D. Mulyana, Metode Penelitian Kualitatif Paradigma baru Ilmu Komunikasi dan Ilmu Sosial (Remadja Rosdakarya, 2014).

28. M. Nazir, Metode Penelitian (Ghalia Indonesia, 2013).

29. S. Adam és S. Widiantoro, J. Appl. Informatics Comput. 3, 96 (2019).

30. A. Sururi, Sawala J. Adm. Negara 3, 1 (2015).

31. Pislawati Alfiaturrahman, J. Valuta 2, 251 (2016). 